\title{
INFLUENCE OF COTTON SOWING DATE ON THE ABUNDANCE OF WESTERN FLOWER THRIPS (Frankliniella Occidentalis) AND ITS PREDATORY BUGS Orius SPP. IN ÇUKUROVA REGION OF TURKEY
}

\author{
Ekrem Atakan $^{1 *}$, Serkan Pehlivan ${ }^{1}$ \\ ${ }^{1}$ University of Çukurova, Faculty of Agriculture, Department of Plant Protection, Adana, Turkey \\ Received - February 02, 2018; Revision - April 05, 2017; Accepted - April 19, 2018 \\ Available Online - April 25, 2018
}

DOI: http://dx.doi.org/10.18006/2018.6(2).358.369

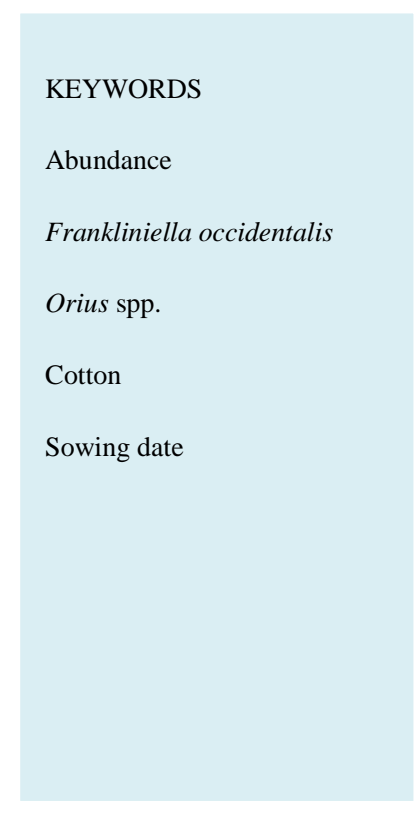

\begin{abstract}
Influence of different cotton sowing dates on densities of pestiferous thrips Frankliniella occidentalis (Pergande) and its predators Orius spp. [Orius niger Wolff and Orius laevigatus (Fieber)] is not clearly understood. The aim of this study is to find best sowing date of cotton to manage populations of thrips and to find out prey-predator interactions in cotton flowers by use of plastic mulching technique. Field experiments were conducted in the Çukurova region of Turkey during the years 2008-2009. Cotton was sown on $1^{\text {st }}-5^{\text {th }}$ March (early sown), $15^{\text {th }}-16^{\text {th }}$ March (early sown), $29^{\text {th }}$ to $30^{\text {th }}$ March (early sown), $15^{\text {th }}$ to $16^{\text {th }}$ April (normal sown) and on $28^{\text {th }}$ April (normal sown). Result of the study suggested that, thrips and its predators shown significantly higher population densities in normal sown than those on early sown cotton $(P<0.05)$. On the other hand significant and positive relationship was reported between thrips and Orius numbers on early-sown cotton (1 March or 5 March $)(P<0.05)$. Numbers of thrips per Orius were very low in most of sampling weeks in June-July period particularly in early-sown cotton (less than 15 preys for one predator) which indicating that, F. occidentalis has a high predation risk by Orius attacks in early-season cotton. Furthermore, higher and significant yield was obtained from earlysown cotton with the plastic mulching technique. Considering the consistent suppression of $F$. occidenatlis by the Orius spp. and significantly high cotton yields, early-mulch-sown of cotton at the beginning of March seems to be a good agricultural practices.
\end{abstract}

* Corresponding author

E-mail: eatakan@cu.edu.tr (Ekrem Atakan)

Peer review under responsibility of Journal of Experimental Biology and Agricultural Sciences.

Production and Hosting by Horizon Publisher India [HPI] (http://www.horizonpublisherindia.in/).

All rights reserved.
All the article published by Journal of Experimental Biology and Agricultural Sciences is licensed under a Creative Commons Attribution-NonCommercial 4.0 International License Based on a work at www.jebas.org.

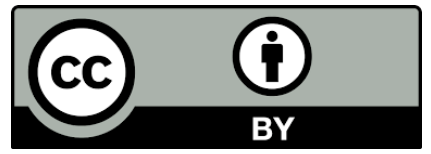




\section{Introduction}

Cotton as many other perennial crops is affected by various climatic conditions such as extended heavy rain falls, wild winds which prolong growing season and delay harvesting. If these undesired climatic factors occurred at late growing season or harvesting time have significantly higher negative effect on cotton yield and quality (Cetin \& Basbag, 2010; Huang, 2016; Sawan, 2017). Therefore, early cotton cultivars have advantage to avoid low temperatures at sowing time, developmental stage of cotton fibers and rainfalls in harvesting time (Ngugi, 1994), and also escape damage of late season pests such as cotton boll worms (Jost \& Cothern, 2001). While, sowing of cotton in late season reduces cotton yield significantly in Turkey (Çopur et al., 2001; Gür et al., 2001). One of the main problems of cotton cultivation in Turkey is rainfall at harvesting time (mostly in September). Rainfall reduces cotton fiber quality and thus, causes cotton price to be low. Recently, sowing of cotton by plastic mulching technique has increased in cotton production in European Countries and China (Dong et al., 2003).The main goal of using this technique is to form a suitable media by providing favorable temperature for development. This system also helps in solving problem associated with the germination of cotton seeds, due to low temperature occurring inside the soil after sowing (Marguez, 1993; Wenging et al., 2017). Plastic mulching technique provides optimum temperature and humidity for quick emergence of cotton seeds, earliness of cotton, and effective control of weeds in naturally grown cotton rows (Fereres \& Goldhamer, 1991; Xue \& Qin, 1992; Ahmad et al., 2015). Additionally, this technique have significant contribution in the growth of cotton plants as compared to conventionally grown cotton (Wendt, 1973; Colomer et al., 1998). Further, plastic mulching increases cotton yield and quality by 10-30\% (Stathakos et al., 2006; Mahajan et al., 2007). Mulch technique has been used in $80 \%$ of the cotton land in the irrigated areas of Spain due to favorable advantage of this sowing system (Robledo de Perdo, 1995). In Turkey, there are few scientific studies carried out on the advantage of plastic mulching technique (Bilgi \& Gençer, 2008).

In Turkey, usually cotton is sowing of in April because in early March soil temperature is very low and this is not allowed to germinate cotton seeds. Early sowing of cotton by using plastic mulching is not yet commonly used practice in Turkey. Sowing of cotton by using this plastic mulching technique at different time may influence abundance of the cotton pest insects and cotton development in the region.

The western flower thrips, Frankliniella occidentalis (Pergande) (Thysanoptera: Thripidae) was reported for the first time in 1999 from the cotton fields of Çukurova region of Turkey and quickly dispersed overall the regions of Turkey. Mostly, Frankliniella flower thrips individuals feeds upon cotton flowers and cause abscission of immature fruiting bodies, causing silver tissues (Atakan \& Özgür, 2001). In Turkey most of the cotton growers frequently used insecticides with high doses; after this also they could not control the population of Frankliniella flower thrips (Kuşdemir et al., 2000). According to Immaraju et al. (1992) and Zhao et al. (1995) uncontrolled application of pesticide, local biotype of $F$. occidentalis has gained resistance against large numbers of commonly used insecticides. The management of thrips is highly difficult because of their vast spreading in most of the cotton growing areas, high reproductive rates, having large numbers of host plants, moreover, insecticides are not effective against pre-adult stages, excluding larvae, because eggs are laid by females into a plant tissue, pre-pupa and pupal stages being mostly in soil or protected sites (Mound, 2009). Therefore, alternative management strategies such as cultural and biological control of $F$. occidentalis in various crops including cotton are often regarded as an important element of integrated pest management strategy (Bournier, 1994). Selection of optimum sowing time is a well-known agricultural practice used to prevent harmful insect's attacks in diverse crops (Saeed \& Razaq, 2014; Devi \& Ram, 2018).

Sowing date may affect the density and abundance of Frankliniella flower thrips and their natural enemies (predatory bugs). Further, cotton flowers are short-lived; thus, flower number and flowering status of plants may influence the population of Frankliniella thrips and their predatory bugs Orius spp. [Orius niger Wolff and Orius laevigatus (Fieber)] which are effectively controlling the flower thrips in non-sprayed cotton fields (Atakan \& Özgür, 2001; Atakan, 2006). According to Micinski et al. (1990), sowing of the cotton between April and Mid-May in Mississippi Delta region, USA did not affect the density of thrips (mainly Frankliniella spp.) and cotton yield was also significantly reduced due to the thrips infestations. Further, it was well reported that sowing time influenced the abundance of some generalist hemipterian predators such as Geocoris punctipes (Say) (Lygaeidae) and Nabis spp. (Nabidae) in cotton (Sprenkel et al., 1979; Sewify et al., 1996). Abundance of coccinellid predator Hippodomia (Adonia), variegata (Goeze) and Orius were appreantly related to cotton sowing date and to the abundance of cotton leafhoppers; fields which were cultivated in early time, proned to get greater densities of predators (Prasifka et al., 2004). In the same ecological area (Çukurova Region), Atakan \& Gencer (2008) investigated population densities of the flower thrips in early (Late-March), normal or timely- (Mid-April or Mid-May) and late (June) sown cotton. These researchers reported reduction in the population of insect pest and natural enemies as well as thrips and Orius in early March sown cotton by using mulchsowing technique. Shrestha \& Parajulee (2010) concluded that the conservation tillage plots of cotton in Texas (USA) has greater numbers of predatory ground beetles (Coleoptera: Carabidae), 
diversity and species richness, and planting date did not significantly influence predatory activity of species, by exluding, Megacephala carolina L. of which abundance was observed to be higher in late-planted cotton than did found in normal-planted cotton.

Present study aimed to investigate the best sowing date of cotton, which was sown by use of mulching technigue, to manage thrips population and to find out relationships between Frankliniella thrips and predatory bugs Orius spp. Additionally, influence of planting date on plant vegetative and generative development and also cotton yields was also estimated. Conclusions may be used in the integrated control of the pest thrips in cotton.

\section{Materials and Methods}

\subsection{Experimental design}

The field experiments were carried out at the Research and Implementation Area of the Çukurova University in the Adana province located at the Çukurova region of Turkey (the eastern Mediterranean region of Turkey). In Turkey, generally cotton is sown between the period 15 April- 15 May (normal-sown cotton). Sowing of cotton after May is often called late-sowing cotton. In some Meriterranean parts of Turkey, cotton is sown in early March but this is not common because of low soil temperature. In this study, influence of sowing date of cotton on abundance of thrips and predatory bugs as well as cotton plant vegetative and generative development and yield was studied. During study, cotton crops are classified as early-sown (March) and convensionally (normally or timely) sown (April or May). SG 125 cotton variety, which has been commonly grown in the area, was sown on $1^{\text {st }}$ March, $15^{\text {th }}$ March and $29^{\text {th }}$ March (early-sown), and $15^{\text {th }}$ April and $28^{\text {th }}$ April (normally sown) in 2008. Cotton was sown on $5^{\text {th }}$ March, $16^{\text {th }}$ March and $30^{\text {th }}$ March (early sown), $16^{\text {th }}$ April and $28^{\text {th }}$ April (normally sown) in 2009. Experimental design was completely randomized block with three replications. Each plot which representing a sowing date was $39.52 \mathrm{~m}^{2}$ with 4 rows of $13 \mathrm{~m}$ length with $0.75 \mathrm{~m}$ row space. Plots were separated from each other by $2 \mathrm{~m}$ (bare soil). There was a $10 \mathrm{~m}$ unplanted area among the blocks. Cotton rows representing the five different sowing time were mulched by using the fine transparent polyethlylene sheets $(0.02 \mu)$ after sowing. The mulch sheets were removed when cotton plants were $10-15 \mathrm{~cm}$ in height. Nearly 20 days after sowing, cotton plants on the rows were thinned to 0.20 $\mathrm{cm}$ at each planting date. $300 \mathrm{~kg} / \mathrm{ha}$ nitrogen was applied to cotton fields at sowing as composed fertilizer, 20-20-0 (N-P-K), and $100 \mathrm{~kg} /$ ha nitrogen (46\% urea) was applied when the first squares appeared. The field experiments were furrow-irrigated at 15 or 20 day intervals when plant terminals with 15 or $20 \mathrm{~cm}$-length became reddish, i.e., water deficiency. Regional routine cultural practices of cotton were performed for all planting date trials in both years. No pesticides was used aganist the pestiferous insects including thrips or acaries in both years.

Plant growth regulator, i.e. Pix ${ }^{\text {TM }}$ (1.1.1. Dimethyl piperidinium chlorine) was applied with doses of 300,400 and $500 \mathrm{cc} \mathrm{ha}^{-1}$ to all plots of experiments before the first, second and third irrigations, respectively in both years. Additionally, Pix with recommended dose of $600 \mathrm{cc} \mathrm{ha}^{-1}$ was also applied to plots of fourth and fifth planting dates of all planting regimes in both experimental years.

\subsection{Monitoring Frankliniella thrips and Orius spp. on cotton flowers:}

Field studies associated with population dynamics of $F$. occidentalis and Orius spp. [Orius niger Wolff and Orius laevigatus (Fieber)] on cotton flowers were carried out at the Balcali location in the years 2008 and 2009. Five fresh flowers (one upper flower from a plant) from each plot representing sowing dates, totally 15 flowers ( 5 flowers $\times 3$ replications) from all plots of each treatment representing different sowing dates were picked randomly at 09:00-10:00 am at weekly intervals. Cotton plants were sampled for numbers of the insects in JuneSeptember (totally 13 sampling dates) in 2008 and in June-August (totally 11 sampling dates) in 2009. Flower samples were placed individually into plastic cups $(250 \mathrm{ml})$ and stored in an ice-chest box and transported to the laboratory. Flowers were exposed to cool for 60 or 90 minutes in a refrigerator and then shaken onto a white plastic container. The thrips and predatory bugs were taken with help of the brush and put in plastic tubes $(2 \mathrm{ml})$ consisting of $70 \%$ ethyl alcohol for identification. Slide-mounted thrips species (adults) were identified by using keys of zur Strassen (2003) and Balou et al. (2012). Flowers were cut into pieces to takeout hidden insects from different flower parts and then agitated in a $2 \%$ detergent solution for 15 seconds. The solutions were spilled through the sieves. Obtained thrips were stored in the plastic tubes $(2 \mathrm{ml})$. Preparations of the thrips (slide-mounting) were made and identified in species level by the first author. Orius species were identified to species level by using their morphological characteristics described in detail by Önder (1982) and Tommasini (2004). Counting of the insects was done under a stereomicroscope with X45 magnifications.

\subsection{Determination of plant characteristics}

According to sowing dates and sowing methods (Aydemir, 1982), plant heights $(\mathrm{cm})$, sowing-squaring day number, flowering day number, boll opening days were measured by selection of 10 plants randomly in each plot. Further, fruiting branch and number of bolls was also counted. For this aim, randomly 10 plants in each plot were selected and observations were done at weekly interval in both years. In order to determine mean boll weight, all 
green bolls of randomly selected 10 plants were hand-picked and weighted.

\subsection{Determination of cotton yield:}

All opened bolls in plots of first, second, third, fourth and fifth sowing dates were hand-picked on 2 August, 14 August, 16 August, 25 August and 30 August, respectively in 2008. Opened bolls in plots of first, second, third, fourth and fifth sowing dates were hand-picked on 5 August, 12 August, 14 August, 23 August and 30 August, respectively in 2009.

\subsection{Data analysis:}

Repeated measure analysis (RM-ANOVA; $P<0.05$ ) was used to evaluate effect of sampling dates and other interactions (sampling date $\times$ year, sampling date $\times$ sowing date, and sampling date $\times$ year $\times$ sowing date) on the abundance of both thrips and Orius. Cumulative mean numbers of thrips or Orius, plant characteristics (mean plant height, fruiting branch, boll number, boll weight) and mean cotton yields were compared by using Tukey's Honestly Significant Difference (HSD) test at $P<0.05$ significant level. Mean numbers of squaring, flowering and boll opening day were evaluated by using same analysis method. Regression analysis (quadratic) was used to investigate relationship between mean numbers of thrips and Orius for each sowing dates in both years at $P<0.05$ significant level. Numbers of $O$. niger and $O$. laevigatus were composed in sampling dates, because $O$. laevigatus individuals were recorded sporadically through the sampling dates in both years. SPSS 13.0 (SPSS, 2000) Statistic Program was used to analyse all data obtained from the study.

\section{Results}

\subsection{Effects of sowing date on thrips abundance:}

Sampling date, interactions between sampling date $\times$ year, sampling date $\times$ sowing date, and sampling date $\times$ year $\times$ sowing date significantly affected thrips densities on cotton sown at different time $(P<0.05$; Table 1$)$. In 2008, sowing date had a significant effect on thrips abundance $(P<0.0001$; Table 1$)$. Thrips densities increased to highest level on cotton sown on $1^{\text {st }}$ March and $15^{\text {th }}$ March at sampling date of $18^{\text {th }}$ June $(F=29.957$, $d f=4.70, P<0.0001)$ and $25^{\text {th }}$ June $(F=21.209, d f=4.70, P<$ 0.000 ) (Figure 1a). Thrips densities were low and fluctuated with the mean numbers of 0.73-0.53 individuals per flower on cotton plants sown (all five dates) until $30^{\text {th }}$ July. Thrips population density on $15^{\text {th }}$ April was the highest and this value (17.7 individuals per flower) was significantly greater than those found in other plots on 30 July $(F=5.148 d f=4.70, P<0.01)$. Mean numbers of thrips were significantly greater on cotton sown on $30^{\text {th }}$ July and $6^{\text {th }}$ August $(F=6.939, d f=4.70, P<0.01)$ than found on cotton plants sown in other sowing dates. Thrips

population showed a significant peak at the sampling date of $13^{\text {st }}$ August with 11.26 \pm 2.92 individuals/flower $(F=9.809, d f=4.70$, $P<0.0001)$ on cotton plants sown at the latest sowing date $\left(28^{\text {th }}\right.$ April). After this sampling date thrips were detected on flowers only on the cotton sown this sowing date.

In 2009, population densities of thrips on cotton plants sown on different dates were usually lower than thrips population on cotton plants observed at previous study-year. Mean numbers of thrips peaked on cotton plants sown on $5^{\text {th }}$ March, $16^{\text {th }}$ March, $30^{\text {th }}$ March and $15^{\text {th }}$ April at the sampling date of $8^{\text {th }}$ July (Figure 1a). These population levels were similar on the plants in these plots, but were significantly greater than those found on the plants sown on $28^{\text {th }}$ April $(F=10.019, d f=4,70, P<0.0001)$. After this date thrips numbers were steadily low in all plots until the sampling date of $29^{\text {th }}$ July. There were significantly greater thrips density levels on the cotton plants sown at the latest date $\left(5^{\text {th }}\right.$ sowing date$28^{\text {th }}$ April $)$ at the sampling date of $29^{\text {th }}$ July $(F=4.596, d f=4,70$, $P<0.05)$ and $5^{\text {th }}$ August $(F=7.786, d f=4,70, P<0.0001)$. After this date thrips were detected only on cotton flowers sown at the latest sowing date (28 April).

Table 1 Effect of sowing date on abundance of Frankliniella occidentalis and Orius spp. in cotton in Adana province, Turkey in 2008 and 2009.

\begin{tabular}{|lcccc|}
\hline \multicolumn{1}{|c}{$\begin{array}{c}\text { Frankliniella } \\
\text { occidentalis }\end{array}$} & df & MS & F & \\
\hline Sowing date & 4 & 384.624 & 11.811 & $* * *$ \\
\hline Year & 1 & 159.125 & 4.886 & $* *$ \\
\hline Sowing date $\times$ year & 4 & 74.059 & 2.274 & NS \\
\hline Date & 16 & 774.363 & 55.453 & $* * *$ \\
\hline Date $\times$ year & 16 & 711.591 & 50.939 & $* * *$ \\
\hline Date $\times$ sowing date & 64 & 126.212 & 9.035 & $* * *$ \\
\hline $\begin{array}{l}\text { Date } \times \text { year } \times \\
\text { sowing date }\end{array}$ & 64 & 78.444 & 5.615 & $* * *$ \\
\hline Error & 2240 & 13.969 & & \\
\hline Orius spp. & & & & \\
\hline Sowing date & 4 & 0.329 & 1.453 & NS \\
\hline Year & 1 & 0.004 & 0.018 & NS \\
\hline Sowing date $\times$ year & 4 & 0.100 & 0.441 & NS \\
\hline Date & 16 & 6.617 & 26.844 & $* * *$ \\
\hline Date $\times$ year & 16 & 4.121 & 16.718 & $* * *$ \\
\hline Date $\times$ sowing date & 64 & 0.407 & 4.651 & $* *$ \\
\hline $\begin{array}{l}\text { Date } \times \text { year } \times \\
\text { sowing date }\end{array}$ & 64 & 0.452 & 6.835 & $* * *$ \\
\hline Error & 1668 & 0.246 & & \\
\hline
\end{tabular}

Journal of Experimental Biology and Agriculture Science http://www.jebas.org 


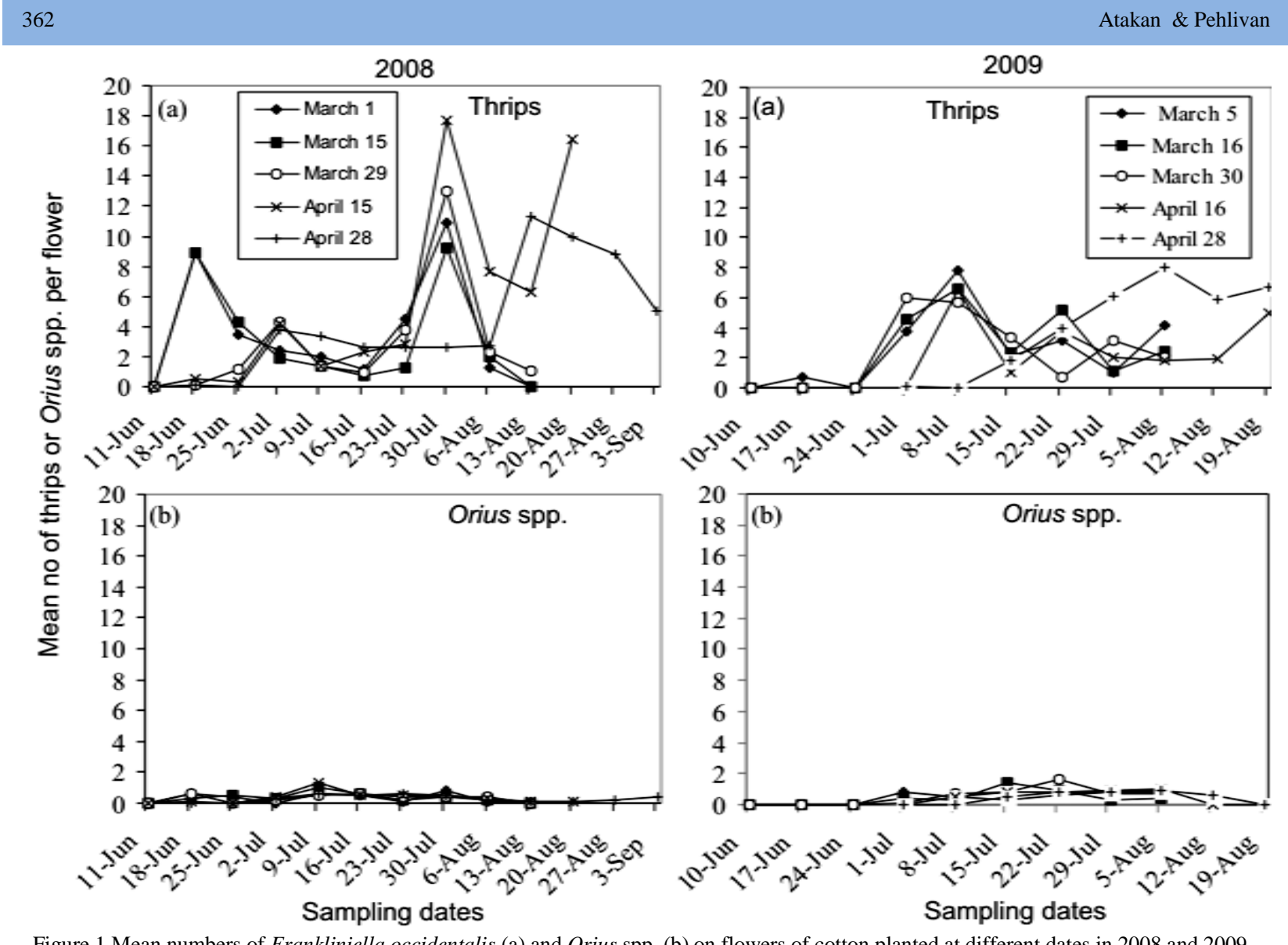

Atakan \& Pehlivan

Figure 1 Mean numbers of Frankliniella occidentalis (a) and Orius spp. (b) on flowers of cotton planted at different dates in 2008 and 2009.

\subsection{Orius abundance}

In 2008, sampling date interactions viz., sampling date $\times$ year, sampling date $\times$ sowing date, and sampling date $\times$ year $\times$ sowing date significantly affected the population densities of Orius spp. $(P<0.05$; Table 1). Furthermore, result of study revealed that sowing dates did not affect abundance of Orius spp. on cotton plants. Orius populations fluctuated with means of $0.10-1$ individual on each flower on cotton plants sown at different sowing dates through the sampling dates (Figure 1b). Mean numbers of Orius spp. on cotton flowers were similar on cotton plants sown at $1^{\text {st }}$ March, $15^{\text {th }}$ March and $29^{\text {th }}$ March, but significantly greater on cotton sown on $18^{\text {th }}$ June $(F=4.763, d f=$ $4,70, P<0.01)$ and on $24^{\text {th }}$ June $(F=6.259, d f=4,70 ; P<0.0001)$ than in normal planted cottons ( $15^{\text {th }}$ April and $28^{\text {th }}$ April) in 2008. Orius population reached to a peak level on flowers $(0.80 \pm 0.26$ Orius per flower) on $30^{\text {th }}$ July in plot of the first planting date $\left(1^{\text {st }}\right.$ March), but this density level was not statistically important than others $(P>0.05)$ in 2008.

In 2009, Orius populations fluctuated with means of $0.20-1.33$ individuals on each flower on cotton plants sown at different sowing dates (Figure 1b). Mean numbers of Orius in the plots of first sowing date (March 5) increased to a peak level with $0.80 \pm 0.24$ individual per flower and this mean number was statistically significant than numbers of other sowing dates $(F=$ 5.951, $d f=4,70, P<0.0001)$. On $15^{\text {th }}$ July, mean numbers of Orius in the plots of second sowing date (March 16) was significantly greater $(1.46 \pm 0.30$ individuals per flower $)$ than sowing dates of $5^{\text {th }}$ March and $28^{\text {th }}$ April $(F=4.134, d f=4,70, P$ $<0.05)$. In general, in late July-early August period, Orius numbers were relatively higher on flowers of cotton sown on $15^{\text {th }}$ April and $28^{\text {th }}$ April, but these levels were not statistically significant $(P>0.05)$ than those found at other sampling dates.

\subsection{Seasonal mean numbers of thrips or Orius on cotton flowers}

Overall, thrips densities on cotton plants were significantly greater on cotton sown on $15^{\text {th }}$ April and $28^{\text {th }}$ April $(F=4.632, d f=4,70$, $P<0.01 ; F=4.670, d f=4,70, P<0.01$, respectively) than those observed on cotton plants sown at other sowing dates in 2008 (Figure 2a). Similarly, thrips densities on cotton plants were significantly greater on cotton sown on $16^{\text {th }}$ April and $28^{\text {th }}$ April 

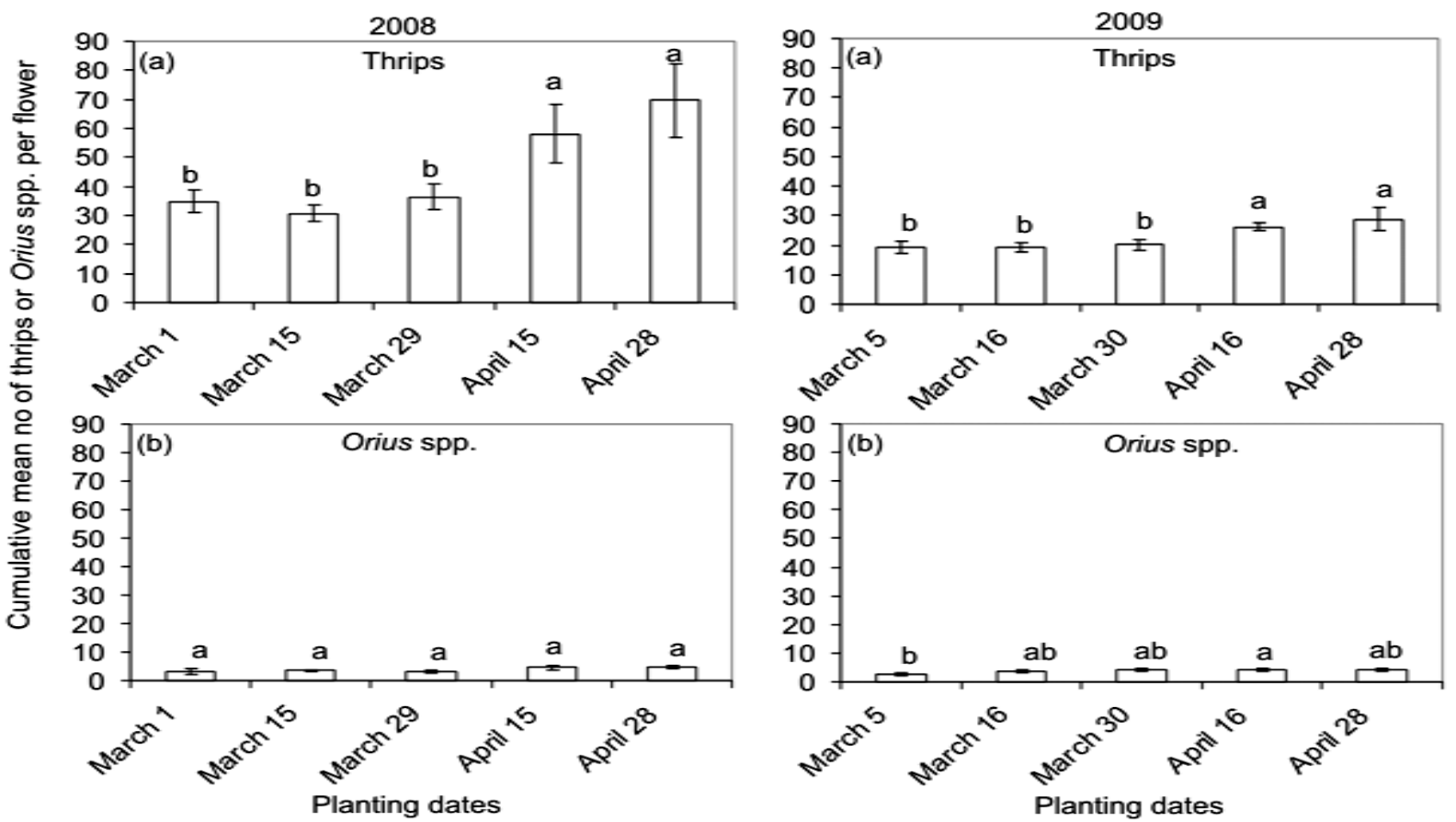

Figure 2 Cumulative mean numbers of Frankliniella occidentalis (a) and Orius spp. (b) on flowers of cotton planted at different dates in 2008 and 2009. Same letters on the bars are not significant according to Tukey's HSD test $(\mathrm{P}<0.05)$.

Table 2 Results of regression analysis between mean numbers of Frankliniella occidentalis and Orius spp. on flowers in cotton planted at different dates in Adana province, Turkey in 2008 and 2009.

\begin{tabular}{|ccccccc|}
\hline Year & Sowing dates & df & $F$ & $R^{2}$ & $P$ value & Equations \\
\hline 2008 & 1 March (early) & 2,9 & 6.110 & 0.63 & 0.029 & $Y=23.20 x^{2}-8.121 x+1.667$ \\
\hline & 15 March (early) & 2,9 & 1.144 & 0.29 & 0.299 & $Y=-14.47 x^{2}-1.765 x+0.353$ \\
\hline 29 March (early) & 2,9 & 2.185 & 0.28 & 0.183 & $Y=-50.72 x^{2}-31.54 x+0.694$ \\
\hline 15 April (normal) & 2,9 & 0.509 & 0.11 & 0.609 & $Y=-39.61 x^{2}+22.01 x+3.143$ \\
\hline 28 April (normal) & 2,9 & 1.205 & 0.20 & 0.344 & $Y=-36.61 x^{2}+22.03 x+3.146$ \\
\hline 5 March (early) & 2,9 & 5.622 & 0.61 & 0.042 & $Y=4.459 x^{2}+1.277 x+0.422$ \\
\hline 15 March (early) & 2,9 & 5.780 & 0.65 & 0,039 & $Y=-8.025 x^{2}+13.23 x+0.043$ \\
\hline 29 March (early) & 2,9 & 1.401 & 0.31 & 0,317 & $Y=-4.088 x^{2}+6.368 x+1.266$ \\
\hline 15 April (normal) & 2,9 & 0.964 & 0.27 & 0.442 & $Y=-11.27 x^{2}+10.53 x+2.424$ \\
\hline
\end{tabular}

$(F=5.743, d f=4,70, P<0.01 ; F=6.215, d f=4,70, P<0,01$, respectively) in 2009. In 2009, cumulative mean numbers of Orius spp. were similar in plots of the first, second and third sowing dates but was the highest $(4.20 \pm 0.57$ Orius spp. individuals per flower) in cotton planted on $15^{\text {th }}$ April (Figure $2 b$ ). Statistically significant difference in means of Orius spp. number was detected between $5^{\text {th }}$ March and $15^{\text {th }}$ April sowing dates $(F=$ 4.595, $d f=4,70, P<0.05)$.

\subsection{Thrips-Orius relationships}

Orius spp. numbers were significantly and positively related to thrips numbers in cotton sown at $1^{\text {st }}$ or $5^{\text {th }}$ March in both years $(P$ $<0.05$; Table 2). While, in case of $16^{\text {th }}$ March, 2009 sown (second sowing date), Orius numbers were significantly and negatively correlated to thrips numbers in cotton $(P<0.05$; Table 2$)$. 


\subsection{Prey-predator ratios}

Prey-predator ratios on cotton plants sown at different time are given in Figure 3. Prey-predator ratio in 2008 varied from, 2:1 to $22.3: 1 ; 3.8: 1$ to $23: 1$ and $1: 1$ to $32.5: 1$ on cotton plants sown early periods at $1^{\text {st }}$ March, $15^{\text {th }}$ March and $29^{\text {th }}$ March respectively,
(Figures 3a, b, c). Prey-predator ratio were low with ratios ranging between $2: 1$ and $38: 1$ at the period of June and July, but apparently high ratio as $94: 1$ and 247:1 on cotton plant sown at $15^{\text {th }}$ April and $18^{\text {th }}$ April (normal plantings) where thrips population peaked in flowers in late season (August) (Figures $3 \mathrm{~d}, \mathrm{e}$ ).
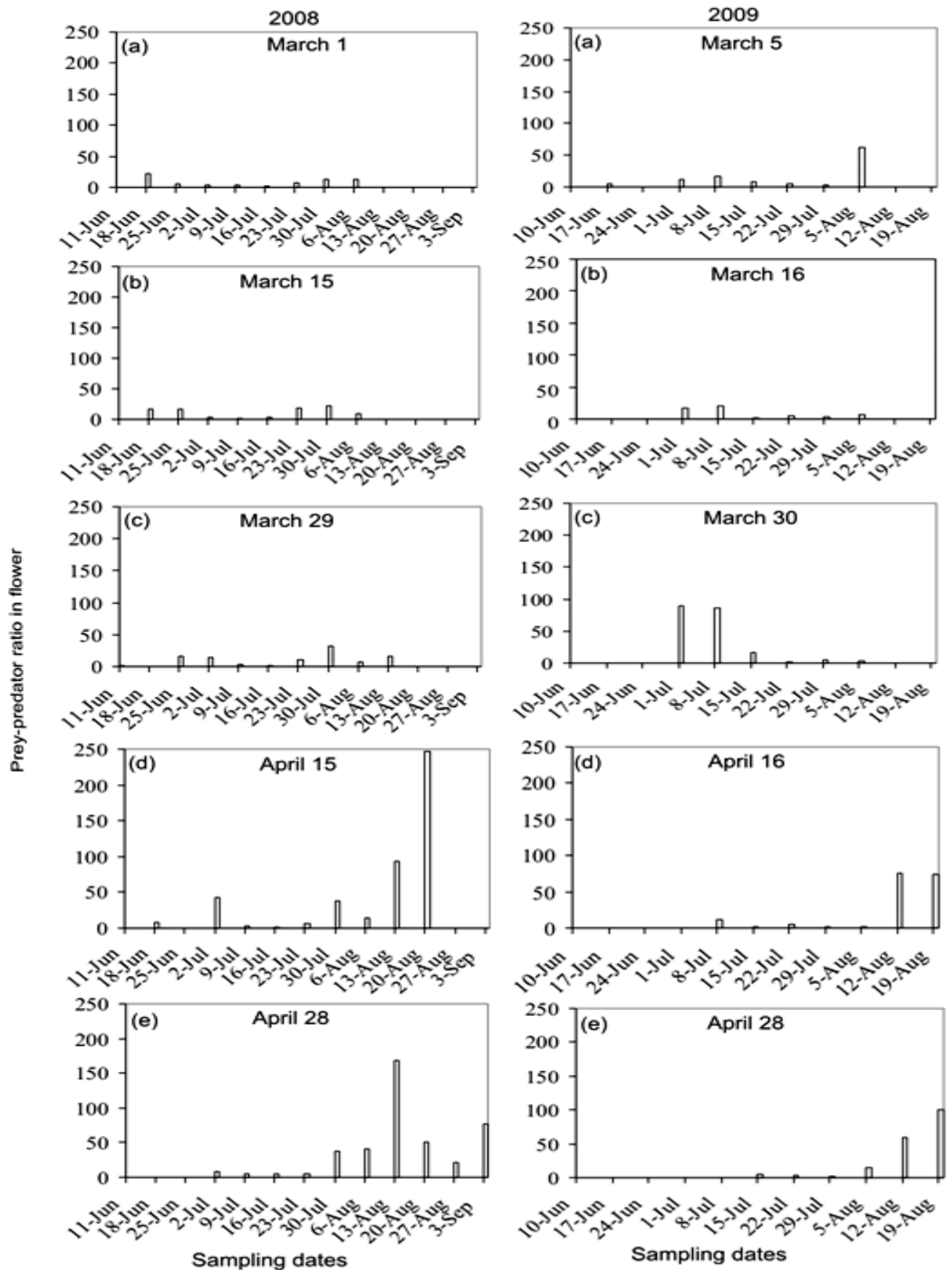

Figure 3 Prey-predator ratios on flowers of cotton planted on March 1 or March 5 (a), March 15 or March 16 (b), March 29 or March 30 (c), April 15 or April 16 (d) and April 28 (e) in 2008 and 2009.

Journal of Experimental Biology and Agriculture Science http://www.jebas.org 
In 2009, prey-predator ratios were lower when compared to previous study-year (Figure 3). Ratios varied from $3.2: 1$ to $62: 1$ and $3.4: 1$ to $17: 1$ on cotton plants sown on $5^{\text {th }}$ March and $16^{\text {th }}$ March planting dates, respectively (Figures 3a, b). Prey-predator ratios ranged between 2.21:1 and 12:1 on cotton plants sown on $16^{\text {th }}$ April (Figure 3d). Prey-predator ratios were less than 15:1 on cotton plants sown on $28^{\text {th }}$ April at the July samplings, but when thrips population increased to a peak level in mid-August, ratio reached 59:1 and 101:1 (Figure 3e).

Overall prey-predator ratios on cotton plants sown on $15^{\text {th }}$ April and $28^{\text {th }}$ April were higher than those found on cotton plants sown earlier (Table 3 ).

\subsection{Determination of plant characteristics:}

Mean plant heights were similar in first and second sowing dates of 2009, but significantly higher than 2008 in first sowing date $P<0.0001$ (Table 4). Like plant height, mean numbers of fruiting branch were similar in first and second sowing dates in 2009, but significantly higher in first planting dates than those of other sowing dates $(P<0.0001)$. Mean numbers of green bolls were significantly higher at first sowing dates of flat sowing technique in 2009 than others $(P<$ $0.0001)$. In general, mean boll weights were similar at sowing dates.

Mean squaring, flowering and boll opening day numbers in cotton sown by different dates are given in Table 5. Mean numbers of squaring, flowering and boll opening days were clearly significantly longer in early sowing date, i.e. March 5 sowing date, than those found in other sowing dates in $2009(P<0.0001)$.

\subsection{Cotton yield:}

Cotton yield in plots of the first sowing date was significantly higher than other sowing dates in 2008 ( $F$ $=189.89, d f=4,10, P<0.0001$; Figure 4). In 2009, cotton yield were similar in plots of March 5, March 30, April 16 and April 28 sowing dates, but significantly lower than that of March 5 ( $F=175.888$, $d f=4,10, P<0.0001 ;$ Figure 4).

\section{Discussion and conclusions}

Abundance of $F$. occidentalis was related to flower densities and flowering pattern of cotton plants sown at different times. In early growing season mean numbers of thrips were greater on cotton plants sown at early
Table 3 Seasonal mean prey-predator ratio (Total thrips: Orius spp.) on flowers in cotton planted at different dates in Adana, province, Turkey in 2008 and 2009.

\begin{tabular}{|ccc|}
\hline Year & Sowing dates & $\begin{array}{c}\text { Prey/predator ratio on one } \\
\text { flower }\end{array}$ \\
\hline 2008 & 1 March (early) & $9.65 \pm 1.18$ \\
\hline & 15 March (early) & $13.04 \pm 2.23$ \\
\hline 29 March (early) & $14.15 \pm 2.21$ \\
\hline 15 April (normal) & $20.22 \pm 6.43$ \\
\hline 28 April (normal) & $21.99 \pm 10.74$ \\
\hline 5 March early) & $5.55 \pm 1.25$ \\
\hline 15 March (early) & $6.98 \pm 1.15$ \\
\hline 29 March (early) & $7.64 \pm 2.41$ \\
\hline 15 April (normal) & $11.72 \pm 1.26$ \\
\hline 28 April (normal) & $11.30 \pm 1.69$ \\
\hline
\end{tabular}

Table 4 Plant development of cotton sown by different technique and dates in Adana province, Turkey during 2008-2009.

\begin{tabular}{|clllll|}
\hline $\begin{array}{l}\text { Sowing } \\
\text { dates }\end{array}$ & $\begin{array}{l}\text { Plant height } \\
(\mathrm{cm})\end{array}$ & $\begin{array}{l}\text { Mean no of } \\
\text { Fruiting branch }\end{array}$ & $\begin{array}{l}\text { Mean no of } \\
\text { boll }\end{array}$ & $\begin{array}{l}\text { Mean no of } \\
\text { boll weight }(\mathrm{gr})\end{array}$ \\
\hline 2008 & March 1 & $99.00 \pm 0.36 \mathrm{a}$ & $13.86 \pm 0.12 \mathrm{a}$ & $19.99 \pm 0.06 \mathrm{a}$ & $6.10 \pm 0.015 \mathrm{a}$ \\
\hline March 15 & $92.73 \pm 1.03 \mathrm{~b}$ & $13.06 \pm 0.06 \mathrm{~b}$ & $22.63 \pm 0.03 \mathrm{a}$ & $5.86 \pm 0.23 \mathrm{a}$ \\
\hline March 29 & $90.90 \pm 0.90 \mathrm{~b}$ & $11.10 \pm 0.10 \mathrm{c}$ & $17.06 \pm 0.16 \mathrm{~b}$ & $5.96 \pm 5.96 \mathrm{a}$ \\
\hline April 15 & $77.96 \pm 0.273 \mathrm{c}$ & $9.50 \pm 0.10 \mathrm{~d}$ & $14.53 \pm 0.16 \mathrm{bc}$ & $5.23 \pm 5.23 \mathrm{~b}$ \\
\hline April 28 & $75.63 \pm 0.68 \mathrm{c}$ & $9.53 \pm 0.03 \mathrm{~d}$ & $15.73 \pm 0.06 \mathrm{~b}$ & $5.40 \pm 5.40 \mathrm{~b}$ \\
\hline & $\mathrm{F}_{4,10}=119.428$, & $\mathrm{F}_{4,10}=501.403$, & $\mathrm{F}_{4,10}=81.523$, & $\mathrm{F}_{4,10}=3.215$, \\
& $\mathrm{P}<0.0001$ & $\mathrm{P}<0.0001$ & $\mathrm{P}<0.0001$ & $\mathrm{P}>0.05$ \\
\hline 2009 & March 5 & $102.33 \pm 1.45 \mathrm{a}$ & $15.67 \pm 0.40 \mathrm{a}$ & $22.06 \pm 0.52 \mathrm{a}$ & $5.60 \pm 0.05 \mathrm{a}$ \\
\hline March 16 & $95.20 \pm 0.47 \mathrm{ab}$ & $14.00 \pm 0.54 \mathrm{ab}$ & $18.96 \pm 0.60 \mathrm{~b}$ & $6.02 \pm 0.06 \mathrm{a}$ \\
\hline March 30 & $88.00 \pm 3.05 \mathrm{~b}$ & $13.00 \pm 0.57 \mathrm{bc}$ & $16.96 \pm 0.63 \mathrm{~b}$ & $6.03 \pm 0.07 \mathrm{a}$ \\
\hline April 15 & $90.20 \pm 2.88 \mathrm{~b}$ & $13.96 \pm 0.33 \mathrm{~b}$ & $19.06 \pm 0.52 \mathrm{~b}$ & $5.60 \pm 0.05 \mathrm{a}$ \\
\hline April 28 & $75.00 \pm 2.88 \mathrm{c}$ & $11.00 \pm 0.53 \mathrm{c}$ & $18.96 \pm 0.60 \mathrm{~b}$ & $5.50 \pm 0.03 \mathrm{a}$ \\
\hline & $\begin{array}{l}\mathrm{F}_{4,10}=18.035, \\
\mathrm{P}<0.0001\end{array}$ & $\begin{array}{l}\mathrm{F}_{4,10}=12.503, \\
\mathrm{P}<0.01\end{array}$ & $\begin{array}{l}\mathrm{F}_{4,10}=10.018, \\
\mathrm{P}<0.01\end{array}$ & $\mathrm{~F}_{4,10}=28.150$, \\
\hline
\end{tabular}

Table 5 Mean squaring, flowering and boll opening day numbers of cotton sown by different technique and dates in Adana province, Turkey in 2009.

\begin{tabular}{|llll|}
$\begin{array}{l}\text { Sowing } \\
\text { dates }\end{array}$ & $\begin{array}{l}\text { Mean number of } \\
\text { squaring day }\end{array}$ & $\begin{array}{l}\text { Mean number of } \\
\text { Flowering day }\end{array}$ & $\begin{array}{l}\text { Mean number of } \\
\text { boll opening day }\end{array}$ \\
\hline March 5 & $80.63 \pm 0.57$ & $97.02 \pm 0.89$ & $140.24 \pm 1.15$ \\
\hline March 16 & $71.14 \pm 0.53$ & $83.12 \pm 0.57$ & $131.45 \pm 1.02$ \\
\hline March 30 & $61.02 \pm 0.42$ & $79.07 \pm 0.42$ & $123.15 \pm 0.93$ \\
\hline April 15 & $52.54 \pm 0.38$ & $68.16 \pm 0.39$ & $107.03 \pm 0.57$ \\
\hline April 28 & $43.19 \pm 0.27$ & $60.23 \pm 0.44$ & $100.12 \pm 0.48$ \\
\hline & $\begin{array}{l}\mathrm{F}_{4,10}=648.900, \\
\mathrm{P}<0.0001\end{array}$ & $\begin{array}{l}\mathrm{F}_{4,10}=606.900, \\
\mathrm{P}<0.0001\end{array}$ & $\begin{array}{l}\mathrm{F}_{4,10}=316.962, \\
\mathrm{P}<0.01\end{array}$ \\
\hline
\end{tabular}




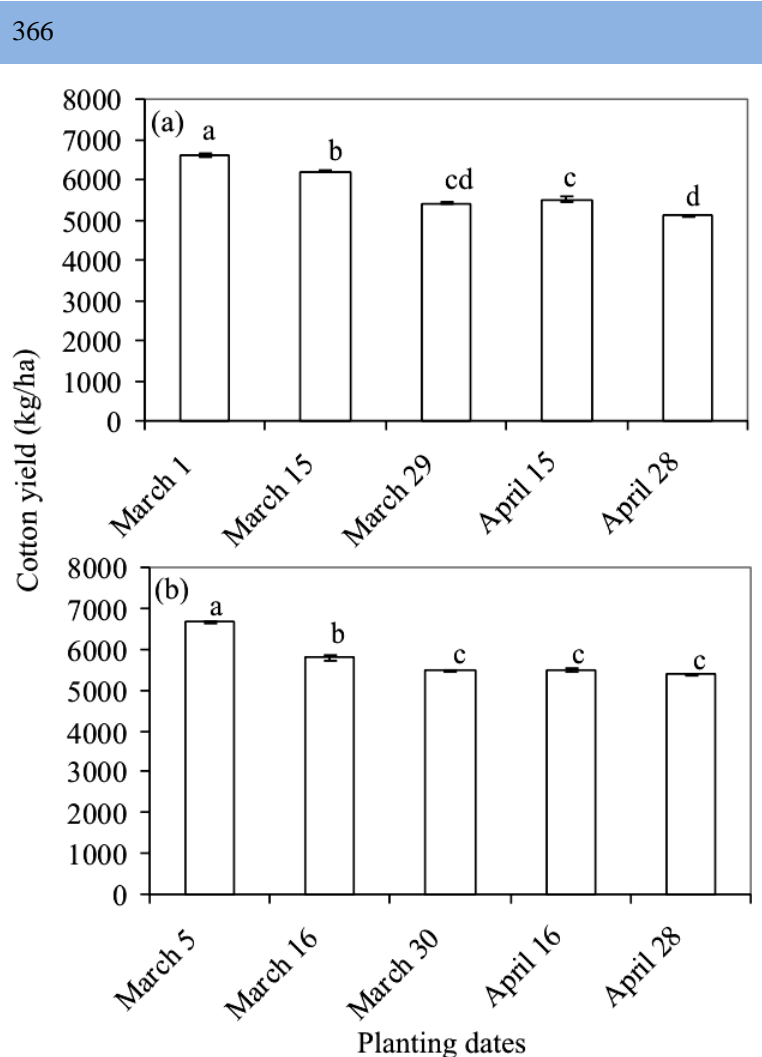

Figure 4 Yields of cotton $\left(\mathrm{kg} \mathrm{ha}^{-1)}\right.$ planted at different dates in 2008 (a) and 2009 (b). Same letters on the bars are not significant according to Tukey's HSD test $(P<0.05)$.

time but in next season, thrips moved to flowers of normal sown cotton. However, the thrips showed main population development in the late-season cotton and its densities were significantly greater on cotton plants sown on normal time (at mid-or lateApril) than those found on cotton plants sown in early time (at March) (Figure 2). The presence of great numbers of $F$. occidentalis at boll maturation period of cotton may be result of movements of the thrips from other nearby weedy plants or summer crops such as cucurbits, to cotton in early-or late August. Furthermore, a few numbers of larval thrips belong to $F$. occidentalis on early-sown-cotton in August as compared to cotton sown in April. Colonization on cotton flowers in earlysown cotton experiments by very high numbers of the adult flower thrips might have negatively influenced eggs laying behavior of females; thus, concluding low ovipositional rate of the female thrips. Although, we did not intent to investigate ovipositional rate of thrips on flowers, some researchers concluded the quality of food affected reproduction of the thrips (Murai \& Ishii, 1982; Kirk, 1985).

No thrips damage on flowers and fruiting parts such as young bolls after the appearance of the flower thrips adults in flowers was observed, that thrips numbers had not reach the economic threshold level as 50-75 thrips adult per flower reported by Atakan \& Özgür (2001) in all sowing regimes.

The abundance patterns of pirate bug Orius spp were similar to the patterns of thrips in cotton flowers. Orius spp. were more abundant on cotton flowers of normal planted date (Figure 1) and overall numbers of Orius spp. was significantly higher in cotton sown in Mid-April (Figure 2). Although in general, Orius densities were relatively greater in late-sown cotton, there were significant and positive relationship between thrips and Orius mean numbers only in early-sown cotton (March 1 or March 5 sowing regime). In previous studies various researchers reported that, populations of $O$. niger significantly and positively correlated with $F$. occidentalis population in normal-planted (lateApril or early-May) cotton (Atakan, 2006; Atakan \& Gencer, 2008). These differences between studies may be because of different sowing date regimes. There was no correlation between Orius insidiosus (Say) and Frankliniella flower thrips abundance in cotton in Quincy and Marianna (USA) which is indicating that $O$. insidiosus may not be an effective predator of Frankliniella tritici (Fitch) (Osekre et al., 2008). As per present study $O$. insidiosus preyed successfully on $F$. occidentalis rather than $F$. tritici and Frankliniella bispinosa (Morgan). Furthermore, it was reported that $F$. occidentalis is the least mobil as compared to others. $F$. tritici individuals are significantly more active than $F$. occidentalis in field-grown peppers (Reitz et al., 2003). However, there was a good relationship between Frankliniella flower thrips and $O$. insidiosus on various cultivated plants in USA (Funderburk et al., 2000; Funderburk et al., 2015). Additionally, in current study, there were many crops such as faba bean, maize, potato and sesame grown nearby, but in previous work of same author, cotton was grown as a sole crop. High plant diversity might have affected insect's abundance and thrips-Orius relationships. Generalist natural enemies such as anthocorids are particularly assumed to benefit from plant diversification, because of the great availability of food sources (Root, 1973; Sheehan, 1986; Russell, 1989).

Prey-predator ratios were much lower in the June-July period than those on late-season in all sowing regimes (Figure 3). However, particularly in normal-planted cotton, prey-predator ratios were over 100 thrips per Orius on flower in late season (August) (Figure 3). This result of present study suggested that flower thrips may suffer more from Orius spp. predation on flowers in early-sown cotton. Lower numbers of thrips in early sowing dates may be an evident of the predator suppression.

There are several factors in suppression of thrips effectively by a predator: the initial population densities of the prey and predator, their fecundity, and morphological structure of host plant (Osekre et al., 2008). Previous studies done in the region reported 
capability of $O$. niger to effectively suppress Frankliniella flower thrips on untreated crop plant such as cotton (Atakan \& Özgür, 2001) and wild plants (Atakan \& Tunç, 2010). There were consistent suppressions of $F$. occidentalis population's overtime particularly in early-sown cotton or in normal-sown cotton, even under higher ratio of thrips-Orius as compared to normal-sown cotton. Prey-predator ratios in most of sampling weeks in JuneJuly period particularly in early-sown cotton were lower (less than 15 preys per predator) than 217 thrips per Orius, which is critical capability ratio for $O$. insidiosus to effectively control populations of F. occidentalis (Sabelis \& Van Rijn, 1997). In current study, significant correlations obtained between numbers of thrips and Orius may be an evident of Orius species mainly $O$. niger becoming an important natural enemy of thrips.

In the current study, early-sown cotton had significant effect on cotton yields (Figure 4). Further, no insect damage as well as thrips was observed in the current study. The higher yield was obtained from early-mulch-sown cotton could be due to long growing season of cotton. Cotton yield in early-March-sown plot (1 March or 5 March) were $23 \%$ higher than cotton sown in lateApril (28 April). Similarly, Bilgi \& Gençer (2008) concluded that mean yield of cotton (same variety-SG125) sown in early-March (7 March) by using plastic mulch were significantly higher (22\% more) than that of cotton sown in late-April (27 April) in the same experimental area. Some researchers reported that late sowing of cotton had relatively less yield in Southern Anatolian region of Turkey (Çopur et al., 2001; Gür et al., 2001). In current study, early-March-sown cotton provided nearly 25 days earlier harvesting of cotton. Our results are agreed with the findings of previous work done in the same experimental area (Bilgi \& Gençer, 2008). In current study cotton planted at March 5 (Early sowing time) had significantly higher green boll load and higher green boll weights than found in others (Table 4). According to the study of Bilgi \& Gençer (2008), number of boll per plant boll weight, thickness and ginning yield were considerably higher in the early-March-sown cotton.

According to data of two years, Frankliniella flower thrips is not regarded as a pest particularly in early-and normal-sown cotton in the region. Therefore, cotton growers in the region do not need to control the flower thrips by insecticide applications in cotton fields. However, it was noted that numbers of lepidopterian pest such as boll worms (Helicoverpa armigera Hubner) were relatively higher than its numbers found in late-sown cotton plots in the experiments, but larval feedings did not cause economic damage (E. Atakan unpublished data). Plants from early- and normal-sown cotton have relatively high numbers of bolls to recover and acquire significant yield.

With respect to result of the cotton yields, and yield parameters of the mulched cotton (Bilgi \& Gençer 2008), early-mulch-sown cotton appears to be a good cultural practice in the Mediterranean region of Turkey and in also other geographical regions sharing similar ecological conditions. With attention to prey-predator associations, this study suggests that Orius spp. (mainly $O$. niger) may be an important natural enemy of Frankliniella flower thrips particularly in early-March-sown cotton. The cost of plastic mulching of cotton in the region is nearly 750 TL (nearly 200 USD) per ha. This extra cost at sowing time will be insignificant by considering favorable advantages of the mulching system in cotton cultivation.

\section{Acknowledgments}

We would like to extend our thanks to Prof. Dr. M. Bora KAYDAN (Vocational School of İmamoğlu, University of Çukurova, Adana, Turkey) and Denis Achiri TANGE (Department of Plant Protection, Faculty of Agriculture, University of Çukurova, Adana, Turkey) for reviewing of the manuscript.

\section{Competing interest}

All authors declare that they have no competing interest financially or non-financially.

\section{References}

Ahmad S, Raza MAS, Saleem MF, Zahra SS, Khan IM, Ali M, Shahid AM, Iqbal R, Zaheer MS (2015) mulching strategies for weeds control and wtaer conservation in cotton. ARPN Journal of Agriculture and Biological Science 10:299-306.

Atakan E (2006) Associations between Frankliniella spp. and Orius niger populations in cotton. Phytoparasitica 34: 221-234.

Atakan E, Gencer O (2008) Influencing of planting date on the relationship between populations of Frankliniella flower thrips and predatory bug Orius niger in cotton. Journal of Pest Science 81:123-133.

Atakan E, Özgür AF (2001) Preliminary investigation on damage by Frankliniella intonsa (Trybom) (Thysanoptera: Thripidae) to cotton plant in Cukurova region of Turkey. In: Marullo R, Mound L (Eds.), Proceedings Seventh International Symposium on Thysanoptera 2-7 June 2001, Reggio Calabria, Italy, Pp: 221-224.

Atakan E, Tunç I (2010) Seasonal abundance of hemipteran predators in relation to western flower thrips Frankliniella occidentalis (Thysanoptera: Thripidae) on weeds in the eastern Mediterranean region of Turkey. Biocontrol Science and Technology 20: 821-839.

Aydemir M (1982) Pamuk Islahı, Yetiştirme Tekniği ve Lif Özellikleri. Tarım ve Orman Bakanlığı, Pak İşleri Genel 
Müdürlüğü, Nazilli Bölge Pamuk Araştırma Enstitüsü Yayınları No:33. Nazilli-Aydın, 1982 (in Turkish).

Balou MM, Tong XL, Chen XX (2012) A new record and description of a new species of the genus thrips with an updated key to species from Iran. Journal of Insect Science 12:1-15.

Bilgi FC, Gencer O (2008) Effects of plastic mulch and different sowing dates on the earliness yield and span technological characteristic in cotton (Gossypium hirsutum L.) varieties. Çukurova Üniversitesi Fen Bilimleri Dergisi 18:131-139.

Bournier JP (1994) Thysanoptera. In: Matthews GA, Tunstall JP (Eds.) Insect pests of cotton. CAB International, Wallingford, Pp: 381-391.

Cetin O, Basbag S (2010) Effects of climatic factors on cotton production in semi-arid regions. Research on Crops 11:785-791.

Colomer M, Lopez M, Gutierrez JC (1998) Physiological effects cotton plant sown under plastic mulch. World Cotton Research Conference-2. New Frontiers in Cotton Research. September 612, 1998, Athens, Greece Volume 1, Pp: 396-400.

Çopur O, Gür MA, Özel A, Oğlakci M (2001) A research on the effects of different planting dates on the boll and fibre technological characteristics of cotton at the Harran Plain conditions-II. In: Proceedings of Fourth National Congress of Field Crops, 17-21 September, 2001, Tekirdağ, Turkey, Pp: 181185 (in Turkish with English Abstract).

Devi S, Ram P (2018) Effect of dates of sowing on population of sucking insect pests in desi cotton (Gossypium arboreum L.). Journal of Entomology and Zoology Studies 6:1041-1044

Dong HZ, Li WJ, Li ZH, Tang W, Zhang DDM (2003) Review on utilization of vegetative branches of cotton plants. Cotton Science 15:313-317.

Fereres E, Goldhamer DA (1991) Plastic mulch increases cotton yield, reduces need for preseason irrigation. California Agriculture 45: 25-28.

Funderburk JE, Stavisky Olson S (2000) predation of Frankliniella occidentalis (Thysanoptera: Thripidae) in field peppers by Orius insidiosus (Hemiptera: Anthocoridae). Environmental Entomology 29:376-382.

Funderburk C, Funderburk Tyler-Julian K, Srivastava M, Knox G, Andersen P, Adkins C (2015) Population dynamics of Frankliniella bispinosa (Thysanoptera: Thripidae) and the predator Orius insidiosus (Hemiptera: Anthocoridae) as influenced by flower color of Lagerstroemia (Lythraceae). Environmental Entomology 44: 668-670.
Gür MA, Çopur O, Özel A, Oğlakci M (2001) A research on the effects of different planting dates on the yield, agronomic, characteristics and earliness of cotton in the Harran Plain Conditions-I. In: Proceedings of Fourth National Congress of Field Crops, 17-21 September, 2001, Tekirdağ, Turkey, pp: 175180 (in Turkish with English Abstract).

Huang J (2016) different sowing dates affected cotton yield and yield components. International Journal of Plant Production 10:63-84.

Immaraju JA, Paine TD, Bethke JA, Robb KL, Newman JP (1992) Western flower thrips (Thysanoptera: Thripidae) resistance to insecticides in coastal California greenhouses. Journal of Economic Entomology 85: 9-14.

Jost PH, Cothern T (2001) Phenotypic alterations and crop maturity differences in ultra-narrow Row and conventionally spaced cotton. Crop Science 41:1150-1159.

Kuşdemir A, Yüzbaş MA, Kisakürek MN, Kanat AD, Güneş M (2000) The damage level and the research of control methods related to the flower thrips (Frankliniella intonsa (Trybom), Frankliniella occidentalis (Pergande) (Thysanoptera. Thripidae) on the cotton in Çukurova. In: Proceedings of the Fourth National Congress of Entomology. Aydın, Turkey, pp: 43-52 (in Turkish with English Abstract).

Kirk WDJ (1985) Pollen-feeding and the host specificity and fecundity of flower thrips (Thysanoptera). Ecological Entomology 10: 281-289.

Mahajan G, Sharda R, Kumar A, Singh KG (2007) Effect of plastic mulch on economizing irrigation water and weed control in baby corn sown by different methods. African Journal of Agricultural Research 2:19-26.

Marquez F (1993) Growing cotton under plastics films. Plasticulture 98:11-18.

Micinski S, Colyer PD, Nguyen KT, Koonce KL (1990) Effects of planting date and early-season pest control on yield in cotton. Journal of Production Agriculture 3: 597-602.

Mound LA (2009) Thysanoptera. In Encylopedia of Insects (edited by VH. Resh and RT. Carde)pp.999-1003. Second Edition, Chapter 254, Academic Press

Murai T, Ishii T (1982) Simple rearing method for flower thrips (Thysanoptera: Thripidae) on pollen. Japanese Journal of Applied Entomology and Zoology 26: 149-154 (in Japanese with English Abstract). 
Ngugi EN (1994) Performance of early and late maturing varieties of cotton (Gossypium hirsutum 1.) in the marginal rainfall areas of Central and East Kenya. In: Constable GA, Forrester NW (Eds). Challenging The Future: Proceeding of the World Cotton Research Conference.-1 CSIRO. Melbourne. Pp. 389-392.

Önder F (1982) Contribution to the study of Turkish Anthocoridae (Heteroptera) (in Turkish), Izmir, Ege University Faculty of Agriculture.

Osekre EA, Wright DL, Marios JJ, Mailhot DJ (2008) Predatorprey interactions between Orius insidiosus (Hetereoptera: Anthocoridae) and Frankliniella tritici (Thysanoptera: Thripidae) in cotton blooms. Journal of Cotton Science 12: 195-201.

Prasifka JR, Heinz KM, Minzenmayer RR (2004) Relationships of landscape, prey and agronomic variables to the abundance of generalist predators in cotton (Gossypium hirsutum) fields. Landscape Ecology 19: 709-717.

Reitz SR, Yearby EL, Funderburk J, Stavisky J, Momol MT, Olson SM (2003) Integrated mangement tactics for Frankliniella thrips (Thysanoptera: Thripidae) in field-grown pepper. Journal of Economic Entomology 96: 1201-1214.

Robledo de Pedro F (1995) La plasticultura espanola en la decada de los noventa. Actas Del I. Simposium Ibleroamericano Sobre Aplicacion De Los Plasticos En Las Tecnologias Agrarias. Almeria 81-92.

Root RB (1973) Organization of a plant-arthropod association in simple and diverse habitats: the fauna of collards (Brassica oleracea). Ecological Monographs 43: 95-124.

Russell EP (1989) Enemies hypothesis: a review of the effect of vegetational diversity on predatory insects and parasitoids. Environmental Entomology 18: 590-599.

Saeed NA, Razaq M (2014) Effect of sowing dates within a season on incidence and abundance of insect pests of canola crops. Pakistan Journal of Zoology 46:1193-1203

Sabelis MW, Van Rijn PCJ (1997) Predation by insects and mites. In Lewis $\mathrm{T}$ (Ed.), Thrips as crop pest, CAB Wallingford, UK., pp: 259-354.

Sawan ZM (2017) Cotton production and climatic factors: studying the nature of its relationship by different stastistical methods. Cogent Biology 3:1-35.
Sewify GH, El-Arnauty SA, Belal MH (1996) The effect of cotton late planting on population densities of sucking insects and their associated predators in Giza region, Egypt. Bulletin of Faculty of Agriculture, Cairo University 47: 665-675.

Shrestha RB, Parajulee MN (2010) Effect of tillage and planting date on seasonal abundance and diversity of predacious ground beetles in cotton. Journal of Insect Science 10: 1-17.

Sheehan W (1986) Response by specialist and generalist natural enemies to agroecosystem diversification: a selective review. Environmental Entomology 15: 456-461.

Sprenkel RK, Brooks WM, Duyn JW, Deitz LL (1979) The effects of three cultural variables on the incidence of Nomuraea rileyi, phytophaghous Lepidoptera and their predators on soybeans. Environmental Entomology 8: 334-339.

SPSS (2000) SigmaPlot user's guide. SPPS Inc., Chiago.

Stathakos TD, Gemtos TA, Tsatsarelis CA, Galanopoulou S (2006) Evaluation of three cultivation practices for early cotton establishment and improving crop profitability. Soil Tillage Research 87: 135-145.

Tommasini MG (2004) Collection of Orius species in Italy. Bulletin of Insectology 57: 65-72.

Wendt CWC (1973) Apply degredable plastic to cotton, onions and carrots in the gigh plains, 1971. In: Degredable plastic mulch studies in West Texas. Cons. Pr-3168-3172. T.A.E.S., College Station Texas, US.

Wenging H, Zhen L, Enke L, Qin L, Dongbao S, Changrong Y (2017) The benefits and challenge of plastic film mulching in China. http://www.world-agriculture.net/article/the-benfits-andchannenge-of-plastic-film (Achieved: $05^{\text {th }}$ March, 2018).

Xue ZX, Qin TS (1992) Cotton cultivation with plastic mulching and seedling trasplanting. In: Li WB, Pen DL. (eds), pratical technigues for cotton growing. Shandog Press for Science and Technology Jinan, China., pp: 160-121.

Zhao G, Liu W, Brown JM, Knowles CO (1995) Insecticide resistance in field and laboratory strains of western flower thrips (Thysanoptera: Thripidae). Journal of Economic Entomology 88: 1164-1170.

zur Strassen R (2003) Die Terebranten Thysanopteren Europas. Verlag Goecke and Evers, Kentern, Germany p. 277 (in Germany) 